\title{
Looking at curriculum implementation from an actor-oriented lens: The case of a Filipino K-12 school
}

Dasas, Louie B. $\bigotimes$

University of Santo Tomas, Philippines (lbdasas@ust.edu.ph)

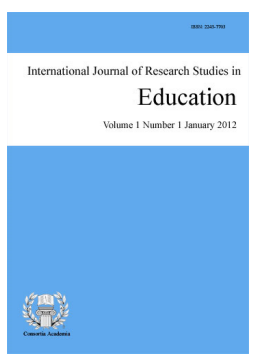

Accepted: 27 September 2021

ISSN: 2243-7703 Online ISSN: 2243-7711

OPEN ACCESS

\section{Abstract}

This study attempted to examine curriculum implementation using an actor-oriented perspective (Penuel et al., 2014). This study involved case study of a top-performing school focused on the role of teachers and processes carried out by teachers during curriculum implementation. Data was gathered using focus-group discussion of teachers and document analysis of sample lesson plans. Findings indicate that teachers remain to be central actors during curriculum implementation. Lesson planning serves as the overt process undertaken by teachers. Covertly, teachers make contextual decisions in lesson planning based on students' levels, needs, and interests. It was also found that school administrators still exert strong influence especially in choosing the lesson plan formats. Findings of this study shed light into the importance of teachers in curriculum implementation. More so, the processes described in this case study may provide insights for practitioners regarding overt and covert procedures to be carried out in implementing a given curriculum.

Keywords: curriculum implementation, actor-oriented perspective, case study, Philippine education, curriculum studies 


\section{Looking at curriculum implementation from an actor-oriented lens: The case of a Filipino K-12 school}

\section{Introduction}

Curriculum implementation refers to how the written curriculum is presented to students; how teaching, learning, and assessment actually happen (UNESCO IBE, 2013). Curriculum implementation regards what is 'actually enacted' and the underlying influences (Century \& Cassata, 2016). Several studies reveal a critical gap between the intended and implemented curriculum (van den Akker, 1988; Spillane, 1999; Songer, Lee, \& Kam, 2002). Inevitably, there is gap between how curriculum designers intend the curriculum to be carried out and what teachers "actually do" in the classroom. As such, there is a need to examine curriculum implementation using the lens of the classroom instruction in order to provide insights regarding processes of implementing the intended curricula (Sarason, 1990; Ng, 2017; 2018).

\subsection{Teachers as key actors in curriculum implementation}

Teachers are identified as key actors in curriculum implementation ((Rogan \& Aldous, 2005; Kimpston \& Rogers, 1986). Teacher's knowledge, skills and motivation (Gross et al., 1971 as cited in Synder et al., 1992) as well as commitment to teaching (Fraser-Thomas \& Beaudoin, 2002; O'Donnell, 2008) were found to be important factors affecting curriculum implementation. Valuable decisions are made by teachers (Turner et al., 2009) based on students' characteristics, school, community, and classroom contexts (Kimspton \& Rogers, 1986; Beauchamp, 1981; Dunkin \& Biddle, 1974). Teachers need to clearly understand the goals of the curriculum (Synder et al., 1992) for it to be successfully implemented. However, a study by Tom (1973) reveal that teachers view curriculum implementation based on pragmatic realms of period-per-period and day-to-day classroom instruction. Such that teachers serve as key actors in curriculum implementation, there is a need to examine the dynamics of decision-making undertaken by the teachers and the processes carried out during curriculum implementation. Teachers as key actors in actual curriculum implementation are emphasized in the actor-oriented perspective proposed by Penuel et al. (2014). This perspective considers how teachers carry out decisions involving curricular purposes and structures with consideration of their prior experience and local [school] contexts.

\subsection{School leaders and curriculum implementation}

School leaders also assume a critical role in actual curriculum implementation because of command responsibility (Virgilio \& Virgilio, 1984). School leaders play the dual roles during actual curriculum implementation; that of a school administrator and an instructional leader. School leaders (as administrators) plan for the different implementation stages which include a) change process, b) communication, c) staff development and training, and d) instructional planning. School leaders also assume the role of an instructional leader who provides assistance to teachers during actual curriculum implementation. In addition, school leaders affect actual curriculum implementation in terms of the school's general ecology and management (Hord \& Hall, 1987; Roehrig et al., 2007).

\subsection{Other Key Actors in Curriculum Implementation}

Aside from teachers and school administrators, parents are identified by literature to be important actors in actual curriculum implementation (Kimpston \& Rogers, 1986; Sturges, 1976). Parents assume some degree of decision-making during actual curriculum implementation given their extent of influence to their children (the students). Other actors involved in actual curriculum implementation are school board members, national department of education, professional organizations, accrediting agencies (both national and international 
accrediting agencies), textbook publishers, and community members (Sturges, 1976). These actors are opposing and have direct or indirect influence on actual curriculum implementation. School board members and the national department of education are involved in policymaking related to actual curriculum implementation. Evaluation standards set by professional organizations and accrediting agencies exert some degree influence in both school administrators and teachers in terms of actual curriculum implementation practices. Textbook publishers also affect actual curriculum implementation through the production of learning materials such as textbooks. Community members, on the other hand, indirectly affect actual curriculum implementation.

\subsection{Purpose of the Study}

In as much as robust literature identifies several key actors involved in actual curriculum implementation, description of the roles of these actors and their extent of influence to curriculum implementation in the class remain to be underexplored. Since teachers are the frontrunners of implementing the curriculum, this study poses relevance by examining the nature of curriculum implementation using an actor-oriented perspective, with teachers in mind. The central focus of the study was to examine the nature of curriculum implementation using an actor-oriented perspective using a case study of a top-performing school. This study focused on finding out the a) role of teachers in curriculum implementation and b) overt and covert processes carried out by teachers in implementing the curriculum.

\section{Methodology}

\subsection{Research Design}

This study made use of a descriptive research design. More specifically, a case study design (Yin, 2018) was utilized to examine how curriculum implementation occurs (Penuel et al., 2014; Fraser-Thomas \& Beaudoin, 2002; Shaw, 1978; Carless, 1998; Hamilton \& Middleton, 2002) in the participating schools involved in this study. Case study arrives at an in-depth understanding of curriculum implementation of the two cases. This is consistent with studies in education that prefer case studies such that they capture a "human face" (Shaw, 1978) that fits the aim of this study to provide understanding of the nature of curriculum implementation from the teachers' view. A top-performing high school was selected based on the mean performance scores in the 2014 National Achievement Test (NAT) administered by the Department of Education in the Philippines. The time for investigation spanned a total of 8 weeks. Albeit not lengthy and extended, the time remains to be appropriately sufficient given the main purpose of the research as well as possible contingencies that arose from the conduct of this study.

\subsection{Data Gathering Procedure}

Data were gathered using focus group discussion and document analysis cognizant to the methods of collection of data inherent to case study research (Yin, 2018; Gerring, 2017; Stake, 1995) and studies on curriculum implementation (Fullan \& Pomfret, 1977). Focus group discussion was conducted with 6 teachers. An actor-oriented framework (Penuel et al., 2014) was used to develop the questions about the key actors involved and their roles in curriculum implementation and the processes undertaken by teachers in implementing the curriculum. Document analysis was also performed using sample lesson plans obtained from the participating school.

\subsection{Data Analysis}

Triangulation is used as a validation strategy especially for qualitative studies such as case study (Gerring, 2017; Yin, 2018). Data triangulation (Leech \& Onwuegbuzie, 2007) was observed following data gathering techniques such as focus group discussion and document analysis. Thematic analysis (Heese-Biber, 2017; Fraser-Thomas \& Beaudoin, 2002) to analyze FGD transcripts. Documents analysis was carried using content 
Dasas, L. B.

analysis (Leech \& Onwuegbuzie, 2005).

\subsection{Research Locale and Participants}

The research locale (School A) is private sectarian educational institution owned and operated by a religious congregation that offers comprehensive basic education (kindergarten, grade school, and high school). It has approximately 4,000 students, 200 teachers, 60 support staff, and 50 administrators. The school enjoys a Level III re-accreditation for both its grade school and high school departments, the highest accreditation for basic education granted by the Philippine Accrediting Association of Schools, Colleges, and Universities (PAASCU). The study involved only the high school department. Table 1 presents the profile of the 6 teacher-participants.

Table 1

Demographic profile $(n=6)$

\begin{tabular}{lll}
\hline Age & & $\%$ \\
\hline $21-25$ years old & 1 & 16.67 \\
$26-30$ years old & 3 & 50 \\
$31-35$ years old & 1 & 16.67 \\
$36-40$ years old & 1 & 16.67 \\
\hline Sex & & 50 \\
\hline Male & 3 & 50 \\
Female & 3 & \\
\hline Status & & 50 \\
\hline Single & 3 & 50 \\
Married & 3 & \\
\hline Years of Teaching & & 33.33 \\
\hline -5 years & 2 & 33.33 \\
5-10 years & 2 & 33.33 \\
$11-15$ years & 2 & 66.67 \\
\hline Years of Teaching in Present School & & 33.33 \\
\hline -5 years & 4 & \\
$5-10$ years & 2 & 33.33 \\
\hline Educational Qualification & 66.67 \\
\hline Bachelor's Degree & & \\
Master's Degree (on-going) & 2 & \\
\hline
\end{tabular}

\section{Results}

\subsection{Focus group discussion of teachers}

Teacher's role in curriculum implementation. Analysis of the FGD with identify several key actors in curriculum implementation which include teachers, school administrators, students, parents, and support personnel. Teachers' roles in curriculum implementation include a) planning role, b) executing role, c) decision-making role, and d) subsidiary role. Teachers assume a planning role by designing lesson plans and brainstorming with colleagues. Teachers play an executing role in curriculum implementation implement the curriculum in the classroom. Having direct contact with students, teachers carry out decision-making roles in curriculum implementation as they continuously decide on what is appropriate. Teachers make decisions about content and approach to teacher and determine if strategies used in the lesson plan are appropriate for the grade level. Teachers pinpoint a subsidiary role that teachers play in curriculum implementation. Teachers are said to strictly follow the curriculum guide as well as directives from school administrators. However, FGD with teachers identify the absence of a written school policy on curriculum implementation. Teachers expressed the need to evolve a written school policy such that translation is not only discussed during faculty meetings and taken up incidentally during professional development seminars.

4 Consortia Academia Publishing (A partner of Network of Professional Researchers and Educators) 
School administrator's role in curriculum implementation. School administrators also serve as actors in curriculum implementation. Teachers point out that the qualities of school administrators affect the manner curriculum is implemented. School administrators must be seen as "able" and committed to resolve conflicts during implementation. Analysis of the FGD reveal several roles that administrators assume in curriculum implementation namely: a) monitoring, b) leadership, and c) mentoring. School administrators assume a monitoring role during actual curriculum implementation by conducting periodic classroom observations and checking lesson plans and assessments. School administrators also monitor the content being taught and activities being carried out in the classroom. Aside from monitoring, school administrators assume a leadership role by overseeing how curriculum implementation is properly carried out. School administrators also lead by providing directives and policies related to curriculum implementation. Lastly, school administrators assume mentoring roles in curriculum implementation. School administrators mentor teachers, especially the new ones, and provide suggestions about content and activities.

Other stakeholders involved in curriculum implementation. Teachers also identify other stakeholders involved in curriculum which includes students and support service personnel. Students provide input during actual curriculum implementation, and they greatly influence the manner of implementation with varying skills levels. On the other hand, support service personnel prepare the needed materials and provide assistance needed during actual curriculum implementation.

Processes carried out by teachers during curriculum implementation. Lesson planning serves as the preliminary process of curriculum implementation as lesson plans provide a guide for organizing the classroom. Teachers make use of the 5Es approach in designing learning processes in the lesson plans. Evidently, school administrators have a personal hand in deciding the learning paradigm to be used in their respective lesson plans.

The teachers identified different sub-processes carried out by teachers in as far as lesson planning as the curriculum implementation process is concerned.

$>\quad$ Formulate of learning targets based on learning competencies. Teachers formulate learning objectives based on the learning competencies. Learning targets are instructional objectives that specify what a learner must attain at the end of one lesson.

$>$ Incorporate the learning competencies in the lesson plan. Teachers include the learning competency together with the LC code from the Department of Education (DepEd) curriculum guide (written curriculum).

$>$ Specify learning objectives based on the DepEd learning competency. Teachers carry out lesson planning by using the DepEd curriculum guide such that learning objectives and activities must be aligned with the curriculum guide. In the case of broad learning competencies and learning activities, teachers extend the objectives but make sure that they are still aligned with the curriculum guide. This is also checked the school administrators (subject area coordinators and academic coordinator).

$>$ Provide opportunities for learners to engage in reflection if learning targets are met. During lesson planning, teachers see to it that the lesson plan contains ample opportunities are given to ascertain if learning targets have been met. Various strategies are employed such as student journals, raising of hands, rating sheets, and short quizzes. Using these strategies, teachers formulate interventions based on perceived student difficulties.

Teachers make contextual decision during curriculum implementation. Additional topics are incorporated by teachers which may not be included in the written curriculum. Based on the interviews, students' interests and aptitudes are considered during the instructional process. This means that teachers do adjustments in the lesson plans to cater to students' interests and aptitudes. For example, more advanced topics are covered for some classes while more drills and exercises are provided to another. Teachers plan their lessons based on the needs of 
the students and design learning activities that are well-suited to the kind of learners.

Several teachers' concerns about lesson planning as a process for curriculum implementation were identified. The lengthy format is seen as time consuming and sometimes confusing because of too many components. Taking a lot of work on the part of the teacher, lesson planning is seen as a burden and a taxing job for teachers. In addition, school administrators having too many expectations makes teachers deviate from the lesson plan especially when not observed by administrators or supervisors. Some teachers feel that their lesson plans are not effective and applicable for all their classes.

\subsection{Document analysis of sample lesson plans}

Sample lesson plans were obtained from the participating school. The selection of the sample lesson plans was determined by the school administrator (Science Area Coordinator). Content analysis was used to perform document analysis of the sample lesson plans in terms of the lesson plan components such as objectives, content, procedures, and assessment.

Understanding by Design (UbD) unit plan as lesson format. Evidently, the lesson plan template followed by School A did not subscribe to DO42 s2016 and instead made use of the Understanding by Design (Wiggins \& McTighe, 2005) or UbD Unit Plan template as the lesson plate template. In the case of School A, a unit plan covers one whole unit which includes several topics and subtopics. The sample unit plan obtained focused on "Life Energy and Processes". This included the topics photosynthesis and cellular respiration. The unit plan includes several Learning Plans that serve the purpose of a daily lesson plan. In the sample unit plan for School A, 1 unit plan was fit for 1 grading quarter covering several weeks of lessons.

\section{Lesson plan components}

Objectives. Standards are derived from the DepEd curriculum guide. UbD unit plan parts such as enduring understandings and essential questions are included. Aside from these, School A's lesson plan includes a Transfer Goal that the long-term accomplishment that students should be able to do on their own using the knowledge and skill acquired (Wiggins \& McTighe, 2005).

The sample lesson plan was for Grade 8 Science, but the LC code is specified in the Grade 9 curriculum guide of DepEd. School A did not follow the spiral progression of Science curriculum as described by DepEd and choose to retain the "disciplinal" approach to teaching Science. Grade 7 takes Integrated Science and Earth Science, Biology for Grade 8, Chemistry for Grade 9, and Physics for Grade 10. Because of this, the learning competencies were drawn from all grade levels $(7,8,9,10)$. In the unit plan, the learning competency is followed by a set of Skills (stated as performance objectives) developed in the lesson formulated following the cognitive domain (Bloom, 1956). No affective nor psychomotor performance objectives are evident in the sample unit plan (lesson plan) of School A.

Teachers also formulate learning targets based on the learning competencies which will be covered for the day's lesson. These are stipulated in every Learning Plan found in Stage 3 of the unit plan. These learning targets result from the "unpacking" or dissecting of learning competencies and skills (performance objectives) enumerated in Stage 1 (Desired Results).

Content. The sample lesson plans place Content and specific lesson topics after Objectives. It can be noted that enrichment topics are included in the lesson plan which are not stipulated in the DepEd curriculum guide. These topics are also found in the enhanced written curriculum being followed.

Procedure. Analysis of the sample lesson plan reveals that the school follows a distinct lesson plan that follows the 5Es instructional cycle. Each part of the 5Es instructional cycle includes bulleted descriptions of lesson procedure as well a guide questions to be used by the teacher. Specific time allotments for each part of the 5 Es instructional cycle are also specified. After the 5Es instructional cycle, a portion for Synthesis is provided.

6 Consortia Academia Publishing (A partner of Network of Professional Researchers and Educators) 
Looking at curriculum implementation from an actor-oriented lens: The case of a Filipino K-12 school

Additionally, the last part of the procedure incorporates Reflection Logs which engages students into reflection questions related to their understanding of the lesson discussed. Specific time allocations for each part of the lesson procedure are also indicated.

Assessment. The UbD template, places the section on Assessment (Stage 2: Evidence) before lesson procedure, faithful to the principle of "backward design". School A describes the Transfer Task (also called Performance Task) using GRASPS (Goal, Role, Audience, Situation, Product/Performance. Standards for Success). It also includes the rubric to be used in grading the performance task. Additionally, the lesson plans include Other Evidence or other assessment tasks such as formative assessments, long quizzes, laboratory activities, and virtual laboratory activities. These are further described in the lesson procedure (Stage 3: Learning Plans) section.

Other lesson plan components. There are several lesson plan components evident in the sample lesson plan obtained which include Remarks, Integration, and Values. The sample lesson plans included remarks and comments by the teacher such as "student enjoyed this activity", "due to lack of time, the teacher helped the students monitor the presence or absence of bubbles by taking a video of their set up". Based on the sample lesson plan, comments from the administrator (subject area coordinator) are reflected in the Remarks/Comments section. School A also provides a section for multiple integration points in the lesson plan. The lesson plans have a unique feature of identifying points of integration in terms of $21^{\text {st }}$ century skills, 7Cs, Philippine Catholic School Standards (PCSS), school's spirituality, distinct core values of school, and multiple intelligences. Also, the plans analyzed have values integration in the lesson procedure, specifying which part of the procedure will values be integrated. The values integrated are inspired by the school's mission-vision, descriptive markings, and spirituality.

\section{Discussion}

Teachers assume the role of main planners and implementers of the lesson plan. However, results indicate the absence of written school policies that describe the teacher's role in curriculum implementation. Although DO42 s2016 was issued by DepEd to serve as Policy Guidelines on Daily Lesson Preparation, findings indicate that there is no written local school policy that makes explicit the teachers' roles and critical decisions to be made by teachers during curriculum translation. In this regard, teachers' experience in the classroom serves as primary basis for curriculum implementation. Thus, there is a need to evolve written school policies on curriculum translation and not solely discussed incidentally during faculty meetings and seminars. This provides new insight into the importance of school policies in decision-making during curriculum implementation (Edgerton et al., 2017).

There lies a problem brought about by unclear benchmark considered by teachers in decision-making regarding content and approach during curriculum implementation. Teachers consider learners' levels and needs as a benchmark for deciding about content and approach in curriculum. This finding agrees with the literature explaining how teacher decision-making during curriculum translation being influenced by students' profile including age, gender, social class as well as students' characteristics namely abilities, knowledge, attitudes (Turner et al., 2009; Kimpston \& Rogers, 1986; Beauchamp, 1981; Dunkin \& Biddle, 1974).

The results also indicate that teachers carry out decisions related to curriculum implementation (particularly adjusting content and approach) based on their own beliefs and goals. In this light, teacher characteristics and orientations having direct influence on curriculum implementation (Synder et al., 1992; Dunkin \& Biddle, 1974). Teachers carry out decisions based on institutional expectations and constraints. This accentuates at the importance of school contexts in teachers' decisions during curriculum implementation (Kimpston \& Rogers, 1986; Beauchamp, 1981).

From the case studied, there is an unclear benchmark to ascertain the degree of fidelity of teachers with respect to the written curriculum since decisions regarding content and approach during curriculum translation. 
As such, there is a need to emerge a taxonomy of 'critical teaching decisions' carried out by teachers (Shavelson $\&$ Stern, 1981). The lesson plan format or template aids the process of curriculum implementation, as revealed by the results of this study. However, the different lesson plan components are not well-grounded on fundamental or emerging instructional theories and are just mere offshoots of seminars or conferences attended by school administrators. It can be said that the findings suggest curriculum implementation lost in the quest for finding the most ideal lesson plan process and format. However, literature point out how a multitude of lesson plan forms or templates that do not embody the essence of the underlying theories thereby 'watering-down' instructional design models (Zazkis et al., 2009). Further, literature suggests how experienced teachers plan for instruction different from those advocated by educational psychologists and theorists (Griffey \& Housner, 1991).

In this light, merely considering the lesson plan format or template makes teachers receive "empty shells that stand in the place of grounded theories of teaching practice" (Zazkis et al., 2009, p. 40). More so, school administrators' over-focus on strictly following lesson plan templates is a sheer representation of curriculum implementation. It oversimplifies what it means to translate the written curriculum and provides a problematic proxy to a dynamic process that should be taking place during curriculum translation, as supported by literature criticizing lesson plan templates (John, 2006). After all, lesson planning places teachers in a crucial position of exploring opportunities to match content with the set standards and the unique contexts of the classroom (Shen et al, 2007).

Results obtained from this study reveal that school administrators directly influence the process of curriculum implementation. School administrators set high expectations that teachers need to faithfully follow the written curriculum during the curriculum implementation process, particularly lesson planning. School administrators expect teachers to carry out lesson planning in a manner that does not dilute the written curriculum. Setting high expectations must be realistic and doable (Bartell, 1989). However, congested curriculum along with lack of materials and resources and low student motivation pose challenge in meeting these expectations. This makes teachers constantly faced with contextual decisions arising from students' needs and adversities in the classroom. Consistent with literature findings, high and often-implicit expectations of school administrators cause teacher anxiety and burnout (Torres, 2016).

The results of the present study reveal how teachers feel pressured over rigorous instructional planning. The pressure comes from rigorous instructional planning that does not show relevance to teachers and their actual practice in the classroom. A lesson plan resulting from rigorous instructional planning does not serve its entire purpose as teachers divert from their plans because they know students better and they decide on what they can do better based on their experiences in the classroom. This finding is consistent with literature describing how teachers feel rigorous lesson planning expectations take too much of teachers' time which they could spend productively on other teaching-related activities (Shen, et al., 2007). "To a certain extent, this rigidity constrains teachers' creativity in designing lesson plans" (p. 251). Further, extensive, and rigorous lesson planning tends to discount learning issues naturally sprouting during lesson delivery in the classroom (Zazkis et al., 2009). Lee and Takahashi (2011) describe how "lesson plans prescribe particular interactional trajectories, but actual teaching may lead to different directions or induce an unexpected turn of events" (p. 210).

This study also points out the seeming problem in variation of contextual decision-making processes carried out by teachers during curriculum implementation. These decisions focus on addressing students' levels and needs and variety of strategies that sustain students' interests. The findings of this study report difference in the curriculum implementation-related (lesson planning) decisions carried out by experienced and inexperienced teachers. This is consistent with literature (Housner \& Griffey, 1985) reporting how experienced teachers focus more on student performance since they possess knowledge structures involving strategies for managing students and facilitating learning that cater to students' individual needs. On the other hand, inexperienced teachers have fewer knowledge structures and years of experience; heavily focus on strategies that sustain the student interest ensuring that students display happiness, task productivity, and remain well-behaved. 
Looking at curriculum implementation from an actor-oriented lens: The case of a Filipino K-12 school

As revealed in the lesson plans, teachers religiously provide documentation of these curriculum implementation decisions. Literature points out the importance of documenting these contextual decisions carried out by teachers during lesson planning, especially to compare practices of experienced and less experienced teachers. Documenting teachers' contextual decisions during curriculum translation can serve the purpose of teacher professional development and an important process for planning for future lessons (Wang \& Paine, 2003).

\section{Conclusions and Recommendations}

This study attempted to examine the nature of curriculum implementation using actor-oriented perspective. The case study involved teachers of a top-performing school. The study sought to describe the role of teachers in curriculum as well as the overt and overt processes carried out by teachers. Teachers are central actors to curriculum implementation. Teachers assume a planning, executing, decision-making, and subsidiary role in curriculum implementation. To a great extent, school administrators also serve as critical actors to curriculum implementation such that they assume monitoring, leadership, and mentoring roles. Lesson planning serves as the central process carried out by teachers during curriculum implementation. Teachers make contextual decisions in planning based on students' levels, needs, and interests. However, lesson plan formats and templates are still highly determined by school administrators. Consequently, this results to teacher-anxiety towards lesson planning as a core process during curriculum implementation. Considering the limitations inherent to this study, the researcher recommends comparing various cases of schools, including low-performing schools, and including classroom observations to gather more data on teachers' practices.

\section{References}

Bartell, C. (1989). Outstanding secondary principals reflect on instructional leadership. The High School Journal, 73(2), 118-128. http://www.jstor.org/stable/40364672

Beauchamp, G. A. (1981). Curriculum theory (4th ed.). Peacock.

Carless, D. R. (1998). A case study of curriculum implementation in HongKong. System, 26(3), 353-368. https://doi.org/10.1016/S0346-251X(98)00023-2

Century, J., \& Cassata, A. (2016). Implementation research: Finding common ground on what, how, why, where, and who. Review of Research in Education, 40(1), 169 -215. https://doi.org/10.3102/0091732X16665332

Dunkin, M., \& Biddle, B. (1974). The study of teaching. Holt, Rinehart and Winston Inc.

Edgerton, A., Polikoff, M., \& Desimone, L. (2017). How is policy affecting classroom instruction? Evidence Speaks Reports, 2(14), 1-9. https://www.brookings.edu/wp-content/uploads/2017/05/es_20170511_polikoff_evidence_speaks1.pdf

Fraser-Thomas, J. L., \& Beaudoin, C. (2002). Implementing a physical education curriculum: Two teachers' experiences. Canadian Journal of Education, 27(2), 249-268. https://doi.org/10.2307/1602223

Fullan, M., \& Pomfret, A. (1977), Research on curriculum and instruction implementation (pp. 335-397). Review of Educational Research, 47(1), 335-397. https://doi.org/10.2307/1170134

Gerring, J. (2017). Case study research: Principles and practices ( $2^{\text {nd }}$ ed.). Cambridge University Press. https://doi.org/10.1017/9781316848593

Griffey, D. C. \& Housner, L.D. (1991). Differences between experiences and inexperienced teachers' planning decisions, interactions, student engagement, and instructional climate. Research Quarterly for Exercise and Sport, 62(2), 196-204. https://doi.org/10.1080/02701367.1991.10608710

Hamilton, C., \& Middleton, H. (2002). Implementing technology education in a high school: A case study. In H. Middleton, M. Pavlova \& D. Robuck (Eds.), Learning in Technology Education: Challenges for the 21st Century (pp. 152-160). Griffith University.

Heese-Biber, S. N. (2017). The practice of qualitative research. Sage.

Hord, S. M., \& Hall, G. E. (1987). Three images: What principals do in curriculum implementation, Curriculum 
Inquiry, 17 (1), 55-89. https://doi.org/10.1080/03626784.1987.11075277

Housner, L. D. \&, Griffey, D. C. (1985). Teacher cognition: Differences in planning and interactive decision making between experienced and inexperienced teachers. Research Quarterly for Exercise and Sport, $56(1), 45-53$. https://doi.org/10.1080/02701367.1985.10608430

John, P. D. (2006). Lesson planning and the student teacher: re-thinking the dominant model. Journal of Curriculum Studies, 38(4), 483-498. https://doi.org/10.1080/00220270500363620

Kimpston, R. D., \& Rogers, K. B. (1986). A framework for curriculum research. Curriculum Inquiry, 16(4), 463-474. https://doi.org/10.1080/03626784.1986.11076018

Lee, Y., \& Takahashi, A. (2011). Lesson plans and the contingency of classroom interactions. Human Studies, 34(2), 209-227. http://www.jstor.org/stable/41478659

Leech, N., \& Onwuegbuzie, A. J. (2007). An array of qualitative data analysis tools: A call for data analysis triangulation. School Psychology Quarterly, 22(4), 557-584. https://doi.org/10.1037/1045-3830.22.4.557

Ng, S. B. (2017, September 22-24). Curriculum implementation and its challenges [Plenary session presentation]. Asia Pacific Conference on Curriculum Studies and Instructional Designing, Ortigas Center, Quezon City, Philippines.

$\mathrm{Ng}$, S. B. (2018). Challenges to curriculum implementation: Reducing the gap between the aspired and its implementation through change management. Asia Pacific Journal on Curriculum Studies, 1(1), 14-19. https://doi.org/10.53420/apjcs.2018.3

O'Donnell, C. L. (2008). Defining, conceptualizing, and measuring fidelity of implementation and its relationship to outcomes in K-12 curriculum intervention research. Review of Educational Research, 78(1), 33-84. https://doi.org/10.3102/0034654307313793

Penuel, W. R., Phillips, R. S., \& Harris, C. J. (2014). Analysing teachers' curriculum implementation from integrity and actor-oriented perspectives. Journal of Curriculum Studies, 46 (6), 751-777. https://doi.org/10.1080/00220272.2014.921841

Roehrig, G., Kruse, R., \& Kern, A. (2007). Teacher and school characteristics and their influence on curriculum implementation. Journal of Research in Science Teaching, 44(7), 883-907. https://doi.org/10.1002/tea.20180

Rogan, J., \& Aldous, C. (2005). Relationships between the constructs of a theory of curriculum implementation. Journal of Research in Science Teaching, 42(3), 313-336. https://doi.org/10.1002/tea.20054

Sarason, S.B. (1990). The predictable failure of educational reform. Jossey Bass.

Shavelson, R. J., \& Stern, P. (1981). Research on teachers' pedagogical thoughts, judgments, decisions, and behavior. Review of Educational Research, 51(4), 455-498. https://doi.org/10.3102/00346543051004455

Shaw, K. E. (1978). Understanding the curriculum: The approach through case studies. Journal of Curriculum Studies, 10 (1), 1-17. https://doi.org/10.1080/0022027780100102

Shen, J., Poppink, S., Cui, Y., \& Fan, G. (2007). Lesson planning: A practice of professional responsibility and development. Educational Horizons, 85(4), 248-260. https://www.jstor.org/stable/42923698

Songer, N. B., Lee, H.-S., \& Kam, R. (2002). Technology-rich inquiry science in urban classrooms: What are the barriers to inquiry pedagogy? Journal of Research in Science Teaching, 39(2), 128-150. https://doi.org/10.1002/tea.10013

Spillane, J. P. (1999). External reform initiatives and teachers' efforts to reconstruct their practice: The mediating role of teachers' zones of enactment. Journal of Curriculum Studies, 31(2), 143-175. https://doi.org/10.1080/002202799183205

Stake, R. E. (1995). The art of case study research. Sage.

Sturges, A. W. (1976). Forces influencing the curriculum. Educational Leadership, 34(1), 40-43. https://files.ascd.org/staticfiles/ascd/pdf/journals/ed_lead/el_197610_sturges.pdf

Synder, J., Bolin, F., \& Zumwalt, K. (1992). Curriculum implementation. In P. Jackson (Ed.), Handbook of research on curriculum (pp. 402-435). Macmillian.

10 Consortia Academia Publishing (A partner of Network of Professional Researchers and Educators) 
Looking at curriculum implementation from an actor-oriented lens: The case of a Filipino K-12 school

Tom, A. (1973). Teacher reaction to a systematic approach to curriculum implementation. Curriculum Theory, 11 (Spring 1973), 86-93. https://doi.org/10.2307/1179349

Torres, A. C. (2016). The uncertainty of high expectations: How principals influence relational trust and teacher turnover in no excuses charter schools. Journal of School Leadership, 26(1), 61-91.

https://doi.org/10.1177/105268461602600103

Turner J. C., Christensen A., \& Meyer D. K. (2009) Teachers' beliefs about student learning and motivation. In L.J. Saha, \& A.G. Dworkin (Eds.), International Handbook of Research on Teachers and Teaching. Springer International Handbooks of Education (vol 21). Springer. https://doi.org/10.1007/978-0-387-73317-3_23

UNESCO IBE. (2013). Glossary of curriculum terminology. http://www.ibe.unesco.org/fileadmin/user_upload/Publications/IBE_GlossaryCurriculumTerminology2 013 eng.pdf

van den Akker, J. (1988). The teacher as learner in curriculum implementation. Journal of Curriculum Studies, 20(1), 47-55. https://doi.org/10.1080/0022027880200104

Virgilio, S. J., \& Virgilio, I. R. (1984). The role of the principal in curriculum implementation. Education, 104(4), 346-350. https://doi.org/10.1123/itpe.4.1.57

Wang, J., \& Paine, L.W. (2003). Learning to teach with mandated curriculum and public examination of teaching as contexts. Teaching and Teacher Education, 19(1), 75-94. https://doi.org/10.1016/S0742-051X(02)00087-2

Yin, R. K. (2018). Case study research: Designs and methods $\left(5^{\text {th }}\right.$ ed.). Sage.

Zazkis, R., Liljedahl, P., \& Sinclair, N. (2009). Lesson Plays: Planning teaching vs. teaching planning. For the Learning of Mathematics, 29(1), 40-47. 
Dasas, L. B.

12 Consortia Academia Publishing (A partner of Network of Professional Researchers and Educators) 